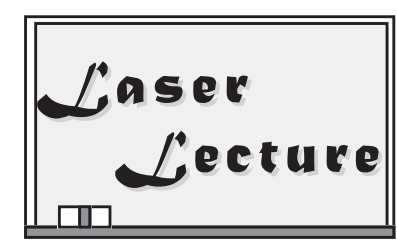

\title{
PID調節計
}

\author{
村上 良明 \\ (株)エム・システム技研 マーケティング部（１１08-0014 東京都港区芝4-2-3 NOF芝ビル1F）
}

\section{PID Controller}

\section{Yoshiaki MURAKAMI}

Marketing Department, M-System Co., Ltd., 4-2-3 Shiba, Minato-ku, Tokyo 108-0014

(Received June 10, 2011)

\begin{abstract}
PID control has been developed as a critical automation technology for more than 70 years. Today it is classified as classical control method, but still widely used, mainly for process automation in steel, petrochemical, chemical, food and other industries. This article introduces basic functions and applications of PID controller, a control device typically used for process automation with examples of actual products in the market.
\end{abstract}

Key Words: Feedback control, PID, Single loop controller, Function block, Combustion control

\section{1. はじめに}

PID制御方式の歴史は古く，1920年代には着想が始ま り30年代にはPID制御方式を実現する調節計の原型が登 場したとされている，今日においては，古典的な制御方 式として分類されているが, それでもなお，産業，医療 機器, 自動車, 航空機などさまざまな分野における制御 に広く活用されている。 とりわけ鉄鋼, 石油, 化学, 食 品などの装置産業におけるプロセスオートメーション (PA: Process Automation)では必要不可欠な自動化技術要 素として主要な位置を占めている。本稿では, 主として PAにおいて使用されるPID制御機能を搭載した調節計 (以下，PID調節計とする)について，製品例を挙げなが ら基本的な機能や応用方法などを中心に解説する。な お, PID制御方式に関する理論的な解説に関しては, 昨 今では著書やインターネット上から多くの情報を容易に 得ることが可能と考えられるため, ここでの詳述は割愛 する。

\section{PID制御と調節計}

\subsection{PID制御について}

PID制御とはフィードバック制御の一種であり，一巡 するフィードバック制御ループにおいて, 目標值 ( = 設 定值, SP: Set Point)に対して測定值 (PV: Process Variable)が一致するように操作量 (MV: Manipulated Variable) を加減する制御方式である (Fig. 1参照)。実際のPAにお いては, 制御対象からPVを発信するセンサ, 制御を行
うPID調節計，MVを制御対象に伝えるアクチュエータ, そして制御対象といった一巡する制御ループが構成され ている。

PID制御では, 比例要素 $(P$ : Proportional), 積分要素 (I: Integral)，および微分要素 $(D$ : Derivative) の組み合わ せ(総和)で操作量が定まる. PID制御の基本的なアルゴ リズムを(1)式に示す。

$$
\begin{aligned}
\mathrm{MV} & =\underbrace{K_{\mathrm{p}} \cdot e}_{\mathrm{p}}+\underbrace{K_{\mathrm{p}} \cdot 1 / T_{\mathrm{i}} \cdot \int e d t}_{\text {比例要素 } I: \text { 積分要素 }}+\underbrace{K_{\mathrm{p}} \cdot T_{\mathrm{d}} \cdot \frac{d e}{d t}}_{D: \text { 微分要素 }} \\
e & : \quad \text { 偏差 }[=\text { 目標值 }(\mathrm{SP})-\text { 測定值 }(\mathrm{PV})] \\
K_{\mathrm{p}}: & \text { 比例ゲイン } \\
T_{\mathrm{i}}: & \text { 積分時間 } \\
T_{\mathrm{d}}: & \text { 微分時間 }
\end{aligned}
$$

上記(1) 式からも明らかなように, 比例要素 $(P)$ は偏 差 $(e)$ に比例して操作量を変える動作を行う。もし，比 例要素のみで操作量が決まるとすれば，偏差が0の時の 操作量で目標値と測定值が一致しない限り，何らかの偏 差が存在することになる。この偏差をオフセット（定常 偏差)と呼ぶ.

積分要素 $(I)$ は, 偏差の時間積分に比例する值で操作 量を変える動作を行う。偏差が0になるまで操作量が変 化するため，比例要素と組み合わせることによりオフ セットを0にすることができる。比例＋積分要素による 制御方式 (PI制御) は, 流量制御や圧力制御など広い範囲 で採用されている。 
PID調節計

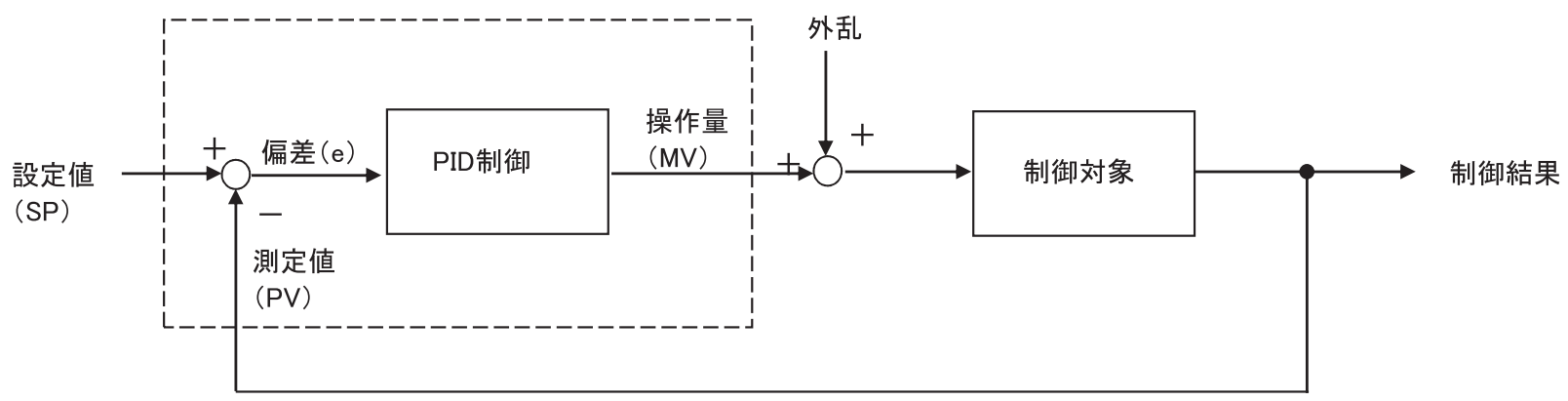

Fig. 1 Basic block-diagram of PID control loop.

微分要素 $(D)$ は, 偏差の時間微分に比例する值で操作 量を変える動作を行う。偏差が変化しない限りその值は 0であり, 比例要素や積分要素の動的な効果を補完する 役割をする. 微分要素は, 熱容量の大きなプロセスや応 答速度の遅いプロセスの制御などにおいて効果を発揮 し, 比例 + 積分 + 微分要素による制御方式 (PID制御) は, 温度制御や成分制御 (例： $\mathrm{pH}$ 值制御) など広い範囲 で採用されている。

これら $P, I, D$ 各要素の効果は, パラメータ $\left(K_{\mathrm{p}}, T_{\mathrm{i}}\right.$, $\left.T_{\mathrm{d}}\right)$ の值によって変化し, それぞれの影響は概ね次のよ うなものである.

・ $K_{\mathrm{p}}$ : この值を大きくすれば, オフセットの幅が小さ くなるが, 制御ループは振動的になる. 大きくし過 ぎると発散する。

・ $T_{\mathrm{i}}$ : この值を小さくすれば, オフセットの収束時間 が短くなる．小さくし過ぎると制御ループは振動的 になり，ついには発散する。

・ $T_{\mathrm{d}}$ : この值を大きくすれば, 制御ループの応答が早 くなる (振動の周期が短くなる). 大きすぎると, 小 さな外乱の影響で操作量が過度に変化する。

実際のPAの制御ループでは, SPを変更した場合や何 らかの外乱によりPVが変動した場合においても, 偏差 が速やかに収束して制御ループが安定した状態に至るよ うに, 制御対象の特性に応じた最適なパラメータの值 (最適值)を与えることが望ましい。ここで, 最適状態を 判断する評価方法にはいくつかの種類があるが, 例えば 振幅減衰比が $25 \%$ ダンピング 評価方法などが良く知られている。 また, 最適值の求め 方としてもいくつかの方法があり, 代表的なものとして $\lceil$ Ziegler Nicholsの方法」, 「高橋の方法」, 「Chien Hrones Reswickの方法」などがよく知られている。 なお, 最近の PID調節計は, 最適パラメータの自動計算(オート チューニング)機能を有する製品が多い.

\subsection{PID 調節計}

PID調節計として, これまでに多くの種類の製品が実
用化されてきた。 古くは, 空気圧力を情報伝達媒体とし た「空気式計器」から始まり, 次にアナログの電気信号を 真空管やトランジスタで増幅・演算処理する「電子式計 器」が登場した。 やがては, その電子部品がIC, LSIへと 進化し，ついにマイクロプロセッサを搭載する製品も現 れた。そして, 現代は単体製品としての調節計から総合 的な制御システムに至るまで, PID制御機能を有する 様々な種類の製品が存在し，それらは下例に挙げるよう なカテゴリに大別できる.

(1)シングルループ・コントローラ ${ }^{\dagger 2}$ : 主としてPA市場 で用いられる，代表的なPID調節計

(2)温度調節計：温度の制御用に特化した調節計

(3)PLC (Programmable Logic Controller)：論理制御を主 体とした制御機器でPID制御機能も搭載可能な製品 が多い

(4)DCS (Distributed Control System) : 主としてPA市場で用 いられる，中〜大規模なプラントの総合制御システム 以下，本稿では，現代のPID調節計の代表として(1)に属 する製品について解説する.

\section{PID調節計の製品例}

\section{1 概要}

Fig. 2に示すのは, 最新のシングルループ・コント ローラ(以下，コントローラとする)の一例であるエム・ システム技研製「SCシリーズ」である，以下に，その概 要を示す.

(1) 外形, 寸法

一般に,コントローラをはじめとするPA用の計器類 は，パネル(計装盤)の表面に実装して使用され，その取 り付け穴(パネルカット)の寸法は, 国際規格(IEC61354/ DIN43700)として規定されている. 従って, メーカや種 類の異なるコントローラやその他の計器でもパネル上に 整然と並べて実装が可能である。

(2) 前面部

前面部には, 表示・操作用のタッチパネル付きカラー

${ }^{\dagger 1}$ 制御ループのSPをステップ状に変化させたとき，振動するPVの波高值が周期ごとに減衰する比率．例えば，波高值が毎周期 $1 / 4 に$ 減衰した場合に $25 \%$ ダンピングと呼ぶ.

${ }^{12}$ DCSが数十ループ分のPID制御を1個のマイクロプロセッサで処理するのに対して, 1ループ分のPID調節計が1個のマイクロプロ セッサを搭載しているためにこのように呼ばれるようになった。 マイクロプロセッサが高級パーツである時代であった. 


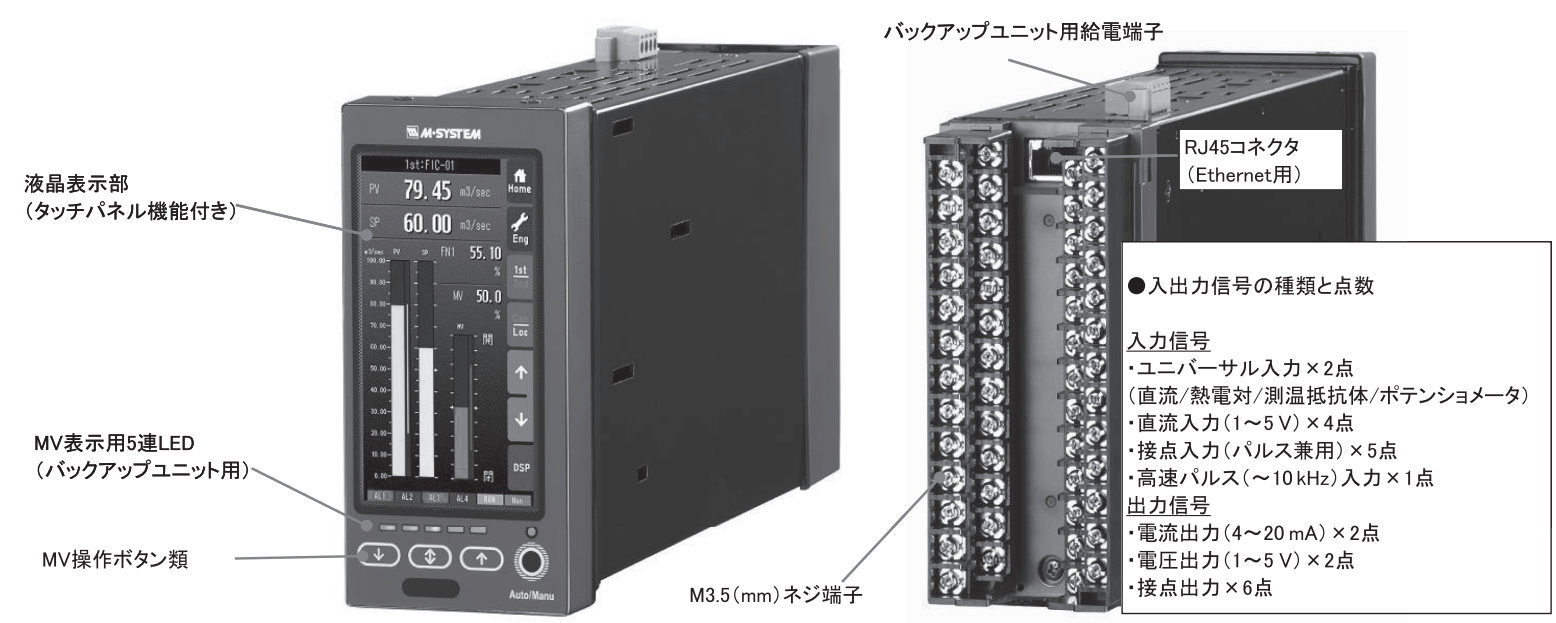

寸法: W72 $\times$ H144 $\times$ D $324(\mathrm{~mm})$

Fig. 2 Product example of Single Loop Controller SC series (Model : SC210), Manufuctured by M-System Co., Ltd..

液晶 $(4.3$ 型TFT, 256 色, $480 \times 272$ ドット)が搭載されて いる。また，液晶の下部には，制御モードの自動/手動 の切り換えボタン, および手動時のMVの操作ボタン類 が配置されている。

液晶には，運転用，およびパラメー夕類の設定用に各 種の画面が表示される。主な画面表示例を下記に示す。

(1)バーグラフ表示画面：PID調節計の典型的な表示パ ターンである。制御ループの変数 (PV, SP, MV)が バーグラフとデジタル值で表示され，ループの状態 が一目で判別できる (Fig. 3). タッチパネルからSP の設定や制御モードの変更などができる。

(2)ショートトレンド表示画面：PV，SP，MVやその他 の内部変数のヒストリカルデー夕(履歴デー夕)を時 系列のトレンドグラフとして表示する。PID調節計 と記録計の機能を併せた利便性の高い表示画面であ る。最新の調節計でのみ実現可能となった (Fig. 4).

(3)チューニング画面： $P, I, \quad D$ のパラメータを設定 (チューニング)するための画面である. 小さなトレ ンドグラフ表示部も付属するので, ループの制御変

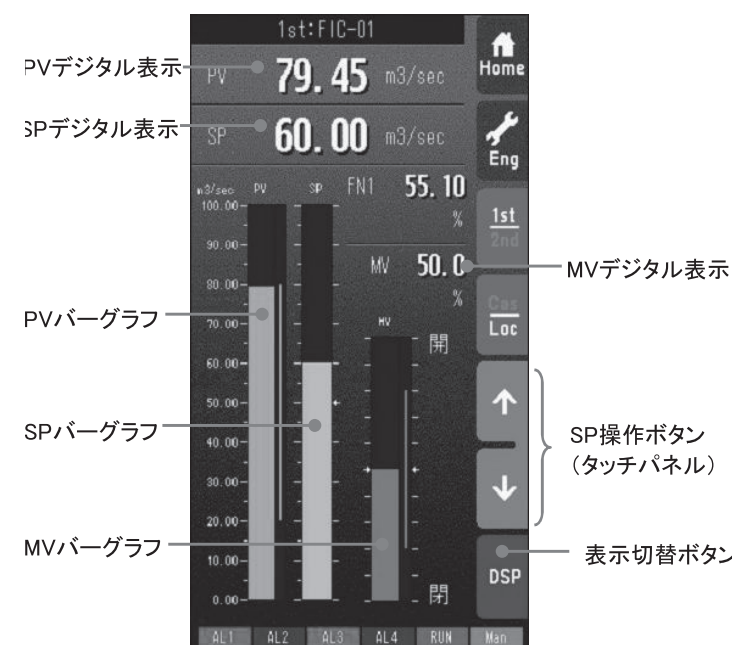

Fig. 3 Bargraph display view.
数の動きを観察しながらパラメータの調節が可能で ある。なお，本製品にはオートチューニング機能が 搭載されているので，パラメータの最適值を自動的 に算出，設定することも可能である(Fig. 5).

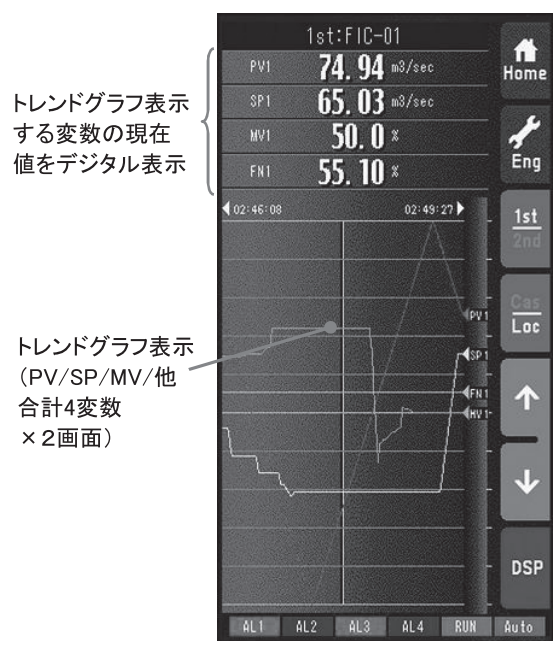

Fig. 4 Short trend view.

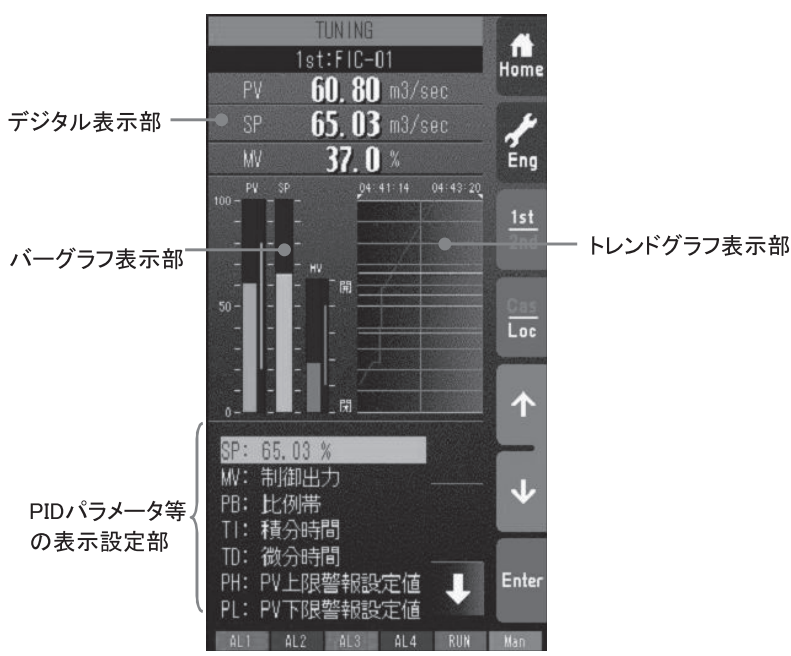

Fig. 5 Tuning view. 
（3）端子台部

計器背面部は，配線用の端子台が取り付けられてお り，ここに制御ループのPVやMVをはじめとする各種の 電気信号 (PID制御以外の各種付帯機能に使用する信号) を接続する (信号の種類と点数はFig. 2参照).

(4) バックアップユニット

コントローラには，MVのバックアップユニットを搭 載したモデルも用意されている。バックアップユニット は, 万一, 調節計の本体が故障した場合においても MV の維持・操作を可能とするためのものであり, 本体とは 独立したハードウェアとして端子台部の内側に実装され ている. Fig. 2に見える前面部の5連LEDはバックアップ ユニットが出力するMVの表示用である. バックアップ ユニット付きの調節計は, PAや発電所などで高い信頼 性が要求される制御対象向けに適用される.

\section{2 制御・演算機能}

コントローラは，基本となるPID制御機能以外にも 様々な制御・演算機能を有する。これらの制御・演算機 能は, 小分割された機能単位でファームウェア化され (これをファンクション・ブロックと呼ぶ), 本体のメモ リ上に実装されている。ユーザは，適切な演算ブロック を選択して組み合わせることによって，目的に応じた制 御内容を実現することができる。主なファンクション． ブロックの種類を以下に示す.

(1)調節器ブロック：基本的なPID制御機能に加え, PV に対する警報設定機能やMVの上下限值制限や変化 率制限など付帯的な機能を持つ。調節器ブロックは 2個実装され，2ループ分までのPID制御ループを構 成できる。

(2)演算器ブロック：下記に大別される各種演算ブロッ クが実装されている。

・一般演算器ブロック：四則演算, 関数演算, 時間 関数演算 (一次遅れフィルタ等), 警報設定, 信号 制限, 信号選択, パルス入力処理, タイマ/カウ ンタ, その他 - 合計40個使用可能

・大型演算器ブロック：折れ線リニアライザ, プロ グラム設定, その他一合計8個使用可能

・シーケンスブロック：論理演算・制御(シーケン ス) 用ブロック - 合計 12 個使用可能 (命令文 最大 1,068 個記述可能）

\section{3 通信機能}

コントローラには，通信機能を備えたモデルも用意さ れている。通信機能には, 以下の2種類がある.

(1)機器間通信：コントローラ間，あるいはコントロー ラと拡張用の入出力ユニット(別製品)間で通信を行 い, ワードデータやビットデータの授受が可能であ
る。通信の物理層はRS485でトークン方式による Peer-to-Peer通信 ${ }^{\dagger 3}$ を行う

(2)上位通信：例えば，パソコン (PC) でコントローラ の持つ情報を収集する場合や，逆にPCからコント ローラへ各種のパラメータを設定するために通信を 行う。通信の物理層は, Ethernet, もしくはRS485

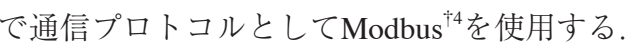

これらの通信機能を使って複数のコントローラやPC でネットワークを構成し，小〜中規模な制御システムを 構築することも可能となり，DCSに準ずる機能を有する システムを実現することができる.

\section{PID調節計の応用例}

\section{1 簡単な応用例 - 熱交換機の温度制御}

PID調節計の簡単な応用例として熱交換機における温 度制御を挙げる (Fig. 6参照)。本例における熱交換機は, 水を蒸気で加温して温水を作る装置である。制御の目的 は熱交換機の出口における温水温度 $(T)$ を一定に保つこ とである，温水温度は，熱媒である蒸気の流量 $(W)$ を変 えることによって制御可能である。ここで, 主な外乱と なるのは水 $(=$ 温水 $)$ の流量 $(Q)$ の変動であり, 外乱に対 しても温水温度の変動を最小に抑えられるように, PID 制御のパラメー夕を調整する。

\section{2 少し複雑な応用例 - ボイラの燃焼制御}

PID調節計の少し複雑な応用例として，コントローラ を2台使用したボイラの燃焼制御の例を挙げる (Fig. 7参 照)。本例におけるボイラは，発電所やプロセス産業な どに設置される，重油を燃料とした一般的な蒸気発生装

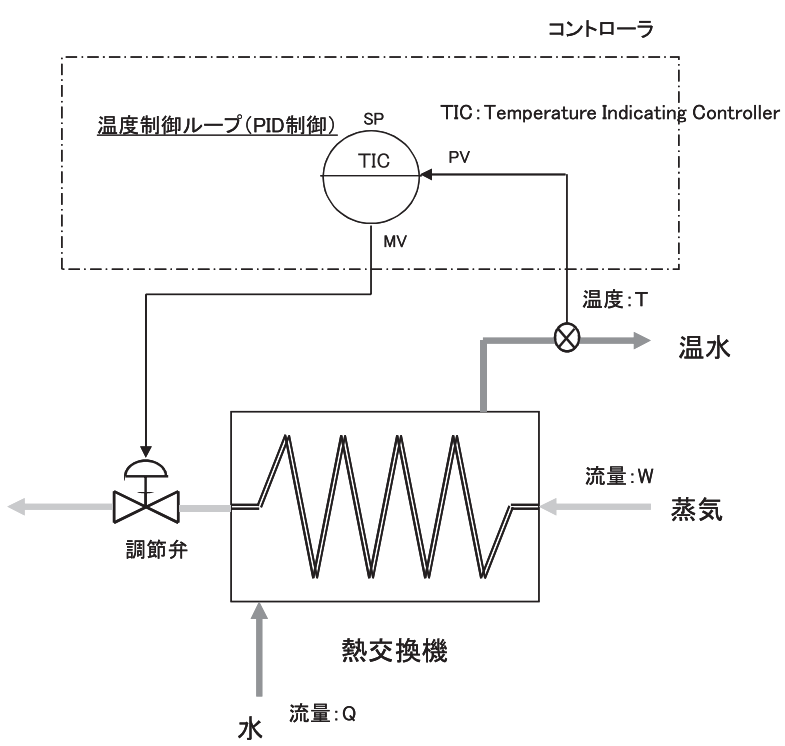

Fig. 6 Temperature control system for heat exchanger.

†゙ネットワーク上の任意の端末間で通信ができるアーキテクチュア。サーバ/クライアント，あるいはマスター/スレーブの位置付け が不要.

${ }^{\uparrow 4}$ Modicon社がPLC用に開発した通信プロトコル。仕様が公開されており，工業計器やPCの通信に広く普及している。基本的にはマ スターハスレーブ方式の通信アーキテクチュア 


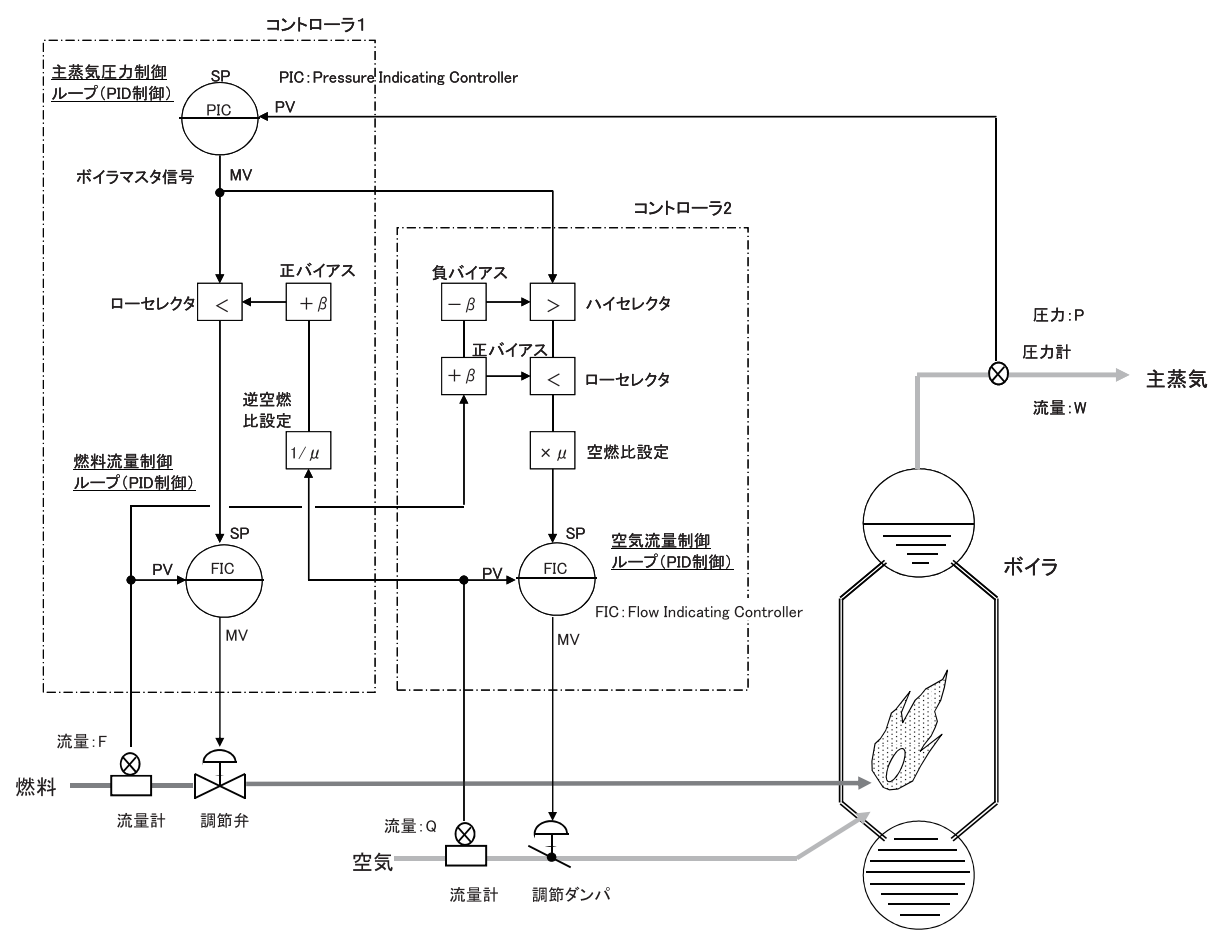

置である.

Fig. 7 Combustion control system for boiler.

ボイラには，燃料とその燃焼用の空気が投入され燃料 の燃焼エネルギーにより蒸気が発生する。ボイラに於け る燃焼制御の主目的は, 発生する蒸気の圧力を一定に保 つことである。ここで, 主な外乱となるのは蒸気流量 $(W)$ の変動, すなわち負荷変動である。 この時, 投入す る燃料の流量 $(F)$ を負荷に追従させ, 発生させる蒸気量 を変更する必要がある。一方, 燃料が燃焼する際には, 燃料の流量に対する適切な空気の流量 $(Q)$ を与える必要 がある。空気の量が過剩であれば加熱された空気により 持ち去られるエネルギーが増えて発生蒸気に対するエネ ルギー効率が低下し, 逆に少なすぎれば不完全燃焼を起 こして燃焼効率が低下するだけでなく，黒煙などを発生 して大気污染の原因ともなるからである。ここで, 空気 と燃料の流量比 $(Q: F)$ を空然比 $(\mu)$ といい, ボイラの運 転においては常に適切な空然比を保つことが重要である (Fig. 8参照).

負荷変動時も空然比が適切に保たれることが望ましい が, 実際のプロセスではどちらかの流量の追従が遅れ る。そのため, 一時的に空燃比は適正值より過大になっ たり，過小になり好ましくない。そこで，このような過 渡的な状態においても適正な空燃比を保つために本例の ような制御手法が採られる(クロスリミット制御とも呼 ばれる)。クロスリミット制御を実現するために，コン トローラではFig. 7に示すようにPID制御ループ以外にも 信号選択(ハイ/ローセレクタ), 加減算, 乗除算などの 演算ブロックが適用され複雑な制御ループが構成されて いる．制御ループの詳細な動作については説明を割愛す るが，主な動作を下記する。
(1)主蒸気圧力制御ループ：PID制御により主蒸気圧力 $(P)$ を一定に制御する。MVは「ボイラマスタ」信号 と呼ばれる。

(2)燃料流量制御ループ: 基本的にはボイラマスタを PID制御のSPとしで5然料流量を制御する。クロス

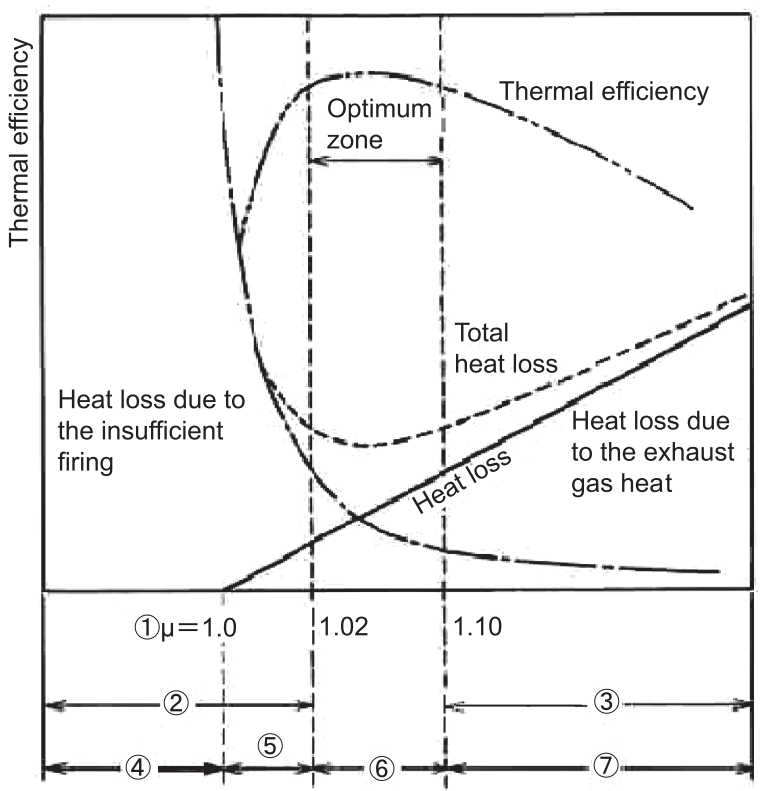
(1) Fuel / Air ratio
(5) Extreme low excess air
(2) Increase $\mathrm{CO}$ and smoke density
(3) Increase $\mathrm{NO}_{x}, \mathrm{SO}_{x}$
(6) Low excess air
(4) Short air
(7) Over excess air

Fig. 8 Relationship between Fuel/Air ratio and combustion status.

\footnotetext{
†5 本例のように，上位のPID制御ループ(図中のPIC)のMVを下位のPID制御ループ(図中のFIC)のSPとして与える制御方式を「カス ケード制御」と呼ぶ.
} 
リミット制御によって, SPが減少する方向の動き に対しては制限がかからないが, 逆に増加する方向 の動きは一定の範囲内に制限される。

(3)空気流量制御ループ: 基本的にはボイラマスタに空 燃比を乗じた值をPID制御のSPとして空気流量を制 御する.SPの可動範囲はクロスリミット制御によ り制限され，過渡時においても常に不完全燃焼にな らないような值が設定される(負荷が増加する時は 燃料流量に対して空気流量が先行して増加し, 逆に 負荷が減少する時は, 空気流量が遅れて減少す る).

\section{5. おわりに}

PID調節計について, 最新の製品例を挙げて解説して きた。冒頭にも述べたように，PID調節計は長い歴史を 持つ製品であるが, 最近はこのようなPID調節計の国産 製品が市場から次第に姿を消している，我が国において プロセス産業の工場が新設されることが少なく, マー ケットサイズが縮小してきたからである。従って, 現 在, 調節計の国内需要の多くは古い調節計のリプレース が目的であると考えられる。しかし，一方ではこのよう なプロセス産業の工場が稼働を続けるためにはPID調節 計はなくてはならない製品であり，その需要が消えるこ とは当分の間はないであろう。

なお，本稿では，応用例などPAに偏向した内容であ るために，読者にはわかりにくい点が多々あったかも知
れない，筆者としては，はなはだ恐縮であるがPID制御 方式はあらゆる分野において応用が可能であり, レー ザー研究に携わる読者諸賢にとって少しでも参考になれ ば幸甚である。

\section{参考文献}

1) 千本資, 花渕 太：計装システムの基礎と応用(オーム社 1987年刊)

2）上記1)の英訳版

Tasuku Senbon, Futoshi Hanabuchi (Eds.): Instrumentation Systems - Fundamentals and Applications (1987 Ohmsha)

3) F. G. Shinskey (岩永 正雄 - 小川積幸 - 栗原 宏文・長山 千五 郎訳)：プロセス制御システム(好学社 1971年刊).

4) 広井和男：PID制御の㧍話(株式会社エム・システム技研広 報誌「エムエスツデー」2-12,2004).

http://www.m-system.co.jp/mstoday 1/MSTback/data/2004/02/ PID_T.htm

5）(株)エム・システム技研システム技術部：データロガー今 昔(「エムエスツデー」1-8, 2006).

http://www.m-system.co.jp/mstoday/plan/serial/ 2006datalogger/01/index.html

6）(株)エム・システム技研：計装豆知識クロスリミット制御 (「エムエスツデー」10,1995)

http://www.m-system.co.jp/mstoday/plan/mame/b_control/9510/ index.html

7）(株)エム・システム技研：計装豆知識 Modbus(「エムエス ツデー」10,1999) 。

http://www.m-system.co.jp/mstoday/plan/mame/ b network/9911/index.html

8）(株)エム・システム技研：プロダクッレビューシングル ループコントローラSC100/200(「エムエスッデー」10, 2010)

http://www.m-system.co.jp/mstoday/backnum/2010/10/sc/index. html 